\title{
Assessing socio-economic condition of sugarcane producers in Nawalparasi district of western nepal
}

\author{
Biwas Bharati*, Rajendra Panta* and Kapil Khanal \\ Institute of Agriculture and Animal Science, Nepal
}

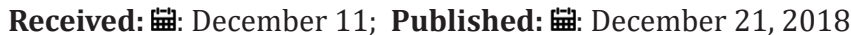

*Corresponding author: Biwas Bharati and Rajendra Panta, Institute of Agriculture and Animal Science, Nepal

\begin{abstract}
A study research was conducted in Nawalparasi district for accessing the Socio-economic conditions of sugarcane producers. Altogether 60 respondents, 30 from Susta Rural Municipalities and 30 from the Pratapur Rural Municipalities involved in sugarcane cultivation were selected for study. For secondary data Desktop review, web surfing, magazine reports, relevant publication, District Agriculture Development Office (DAD0) and Agriculture Service Centre (ASC) were consulted. Information were collected and analyzed by using descriptive statistics, gross margin, and Benefit Cost (BC) analysis. The major respondents involved in sugarcane production were found to be male. The main source of income was found to be agriculture in both Rural Municipalities. The major expenses occupied by variable cost were labor cost (in Rs) followed by sett cost, cost of fertilizer, transportation, irrigation and insecticide. The gross return per hectare was Rs 2,70,222.30 and net profit per hectare for sugarcane production was Rs 1,02,826.2 found to be more profitable crop in the study area. The analysis of total variable cost, gross margin and B/C ratio revealed that sugarcane production is most profitable business. Lack of irrigation, fertilizer and labor were major production constraints whereas late payments, large number of middlemen were key marketing problems.
\end{abstract}

Keywords: B/C Ratio; Gross Margin; Irrigation; Late Payment; Sugarcane

\section{Introduction}

Sugarcane (Saccharum officinarum) is one of the most important crops in the world because of its strategic position and immense use in the daily life of any nation as well as for industrial uses aimed at nutritional and economic sustenance. Sugarcane contributes about $60 \%$ of the total world sugar requirement while $40 \%$ came from sugar beet [1]. It is a tropical crop that usually takes between $8-12$ months to reach its maturity. The crop is usually produced from stem cuttings called setts and each node has all the qualities for growing new plants. The shoots grow from underground nodes, and the axillary buds at these nodes give rise to tillers [2]. Most of the people are engaged in sugarcane in Terai. It is the main source of income in Terai as it provides the raw materials for large number of industries. The productivity of sugarcane in world is $57,500 \mathrm{~kg} /$ ha [3]. According to Ministry of Agriculture Development [4] $2015 / 2016$, the net area under sugarcane cultivation in Nepal is 80931 ha with production of $4346754 \mathrm{Mt}$ and productivity $53709 \mathrm{~kg} /$ ha and it covers an area of 7438ha in Nawalparasi with production $462825 \mathrm{Mt}$ and productivity $62224 \mathrm{~kg} / \mathrm{ha}$. Socioeconomic status is the social standing or class of an individual or group. It is often measured as a combination of education, income and occupation.
The sugarcane has been playing vital role in reducing poverty, socio-economic advancement. The socio-economic advancement is affected by the fluctuation in price of sugarcane.

\section{Materials and Methods}

The research was conducted in Nawalparasi district, in western development region. A restructured questionnaire was used for collecting and analyzing data upon which this study is based. The respondents were selected by simple random sampling by sampling frame of sugarcane producers and altogether total 60 samples were taken for the study among all the sugarcane growing farmers, 30 from the Susta and 30 from the Partapur rural Municipality. The primary informants were the commercial sugarcane growers and beside them the key informants were also consulted whenever necessary. The secondary data were taken from the number of publications of related organizations like Ministry of Agriculture and Development [4], Central Bureau of Statistics (CBS), DADO of respective district and agricultural cooperatives. The sets of questionnaires for the commercial sugarcane growers were used to collect the primary data by face to face interview. The data analysis 
was done with the help of Statistical Package for Social Science (SPSS). Various problems and suggestions were ranked with the use of index. Similarly, different analytical terminologies were used during the analysis.

a) Gross margin = sale value - variable cost

b) Total cost $=\sum$ Cost incurred in all variable cost

c) $\mathrm{B} / \mathrm{C}$ ratio $=$ Gross return $/$ Total cost

\section{Result and Discussion}

$83 \%$ and $87 \%$ of the respondents practicing sugarcane farming in Susta and Pratapur rural Municipalities were male and the female practicing sugarcane farming was consecutively $17 \%$ in Susta and 13\% in Pratapur Municipality. 58.33\% was the joint family of the respondent involved in sugarcane farming. The average age of the respondent practicing sugarcane farming was 51.38 year. Growing sugarcane considers a heavy expenditure on different inputs among which maximum expenses was seen occupied by labor cost (Rs 80565.75). The labor is required for different kind of cultivation practices. The labor cost was followed by cost of sett (Rs 41747.30). The cost of sett was followed by fertilizer (Rs 19543.62), transportation (Rs 17719.72), insecticide (Rs 1325.27) and the total expense (variable cost) per hectare was found to be Rs 167396.40. The gross return per hectare was Rs 270222.30 and net profit for sugarcane production was Rs 102826.2 and thus sugarcane was found to be more profitable crop in the study area. The gross margin was found to be Rs 102826.20 for the land area per hectare. The BC ratio was found to be 1.677 for Susta rural Municipality and 1.558 for Pratapur rural Municipality.

The overall BC ratio per ha was 1.615. The total productivity from the Susta and Pratapur rural Municipality was found greater than the productivity of Nepal but when compared with Nawalparasi was found less. Two types of marketing channel were found in both Susta and Pratapur rural Municipality. After the harvesting of cane, the sugarcane was loaded and transported to the crusher/sugar mill. The involvements of middlemen were found higher between farmer and sugar mill/crusher which affects in the profit of farmer. The different production problems faced by the farmer were ranked with the help of index value. Among the several problems, lack of irrigation was ranked first with an index value (1.196). The other problems that are present with the sugarcane cultivation ranked after irrigation are lack of fertilizer, labor shortage, insect's pest incidence, prominent weeds, lack of technological advancement and the long procedure for obtaining agricultural loan with index value of $1,0.996,0.78,0.7,0.55$ and 0.39 respectively.
The first ranked marketing problems as perceived by the farmers were Late payment with an index value 0.954 followed by Middleman with an index value of 0.754 , Large number of crushers with an index value of 0.420 and Variable rate with an index value of 0.370. Sugarcane cultivating farmers suggested to increase the facility of irrigation arrangement which was given first rank with index value of 0.82 . Availability of labor, fertilizers, training on insect's pest control and easy access to improved variety of sugarcane were among the rest suggestion given by farmers with $0.7,0.63,0.48$ and 0.38 index value respectively. The first ranked suggestion to reduce marketing problem as perceived by the farmers were direct payment by sugar mill with an index value 0.90 followed by reduction of middleman with an index value of 0.71 which was then followed by reduction in number of crusher and fixing the sugarcane rate consecutively with an index value of 0.48 and 0.45 respectively. The result revealed that the contribution of sugarcane farmer in total income of Susta rural Municipality was 23.7\% while that of Pratapur rural Municipality was 25.45\%.

\section{Conclusion}

Although sugarcane is one of the most important crops of Susta and Pratapur rural Municipality of Nawalparasi district, it requires improvement by providing easy supply of the inputs required in the production and reducing the problem of marketing to ensure the maximum profit for the sugarcane farmers. Farmers are following traditional farming system, which does not provide the adequate income for their living. Low cost technology is a need for the farmer to bring down the cost of cultivation. The marketing channel also does not follows an organized way. If the government provides good prices of crop sale and low-cost input technology for the farmers, then the problem of unemployment can be solved. Net profit from the sugarcane indicated that this crop is valuable in relation to income generation and livelihood improvement. With coverage of such area for cultivation and sugarcane not being a staple crop proves its preference, potential, importance and status among farmers in Nawalparasi district.

\section{References}

1. Onwueme IC (2005) Crop Science: Tropical agricultural series. Cassell London, pp. 89-90.

2. Takamura YT, Tarimo AJP (1998) Sugarcane production, processing and marketing in Tanzania. African Study Monographs 19(1): 1-11.

3. (2010) Food and Agriculture Organization (FAO). Sugarcane world production.

4. (2016) Government of Nepal, Ministry of Agricultural Development. Statistical information on Nepalese agriculture. Monitoring, Evaluation and Statistics Division Agri Statistics Section, Singh Durbar, Kathmandu, Nepal. 


\section{ISSN: 2574-1241}

DOI: $10.26717 / B J S T R .2018 .12 .002264$

Biwas Bharati, Rajendra Panta. Biomed J Sci \& Tech Res

CC (i) This work is licensed under Creative

Submission Link: https://biomedres.us/submit-manuscript.php

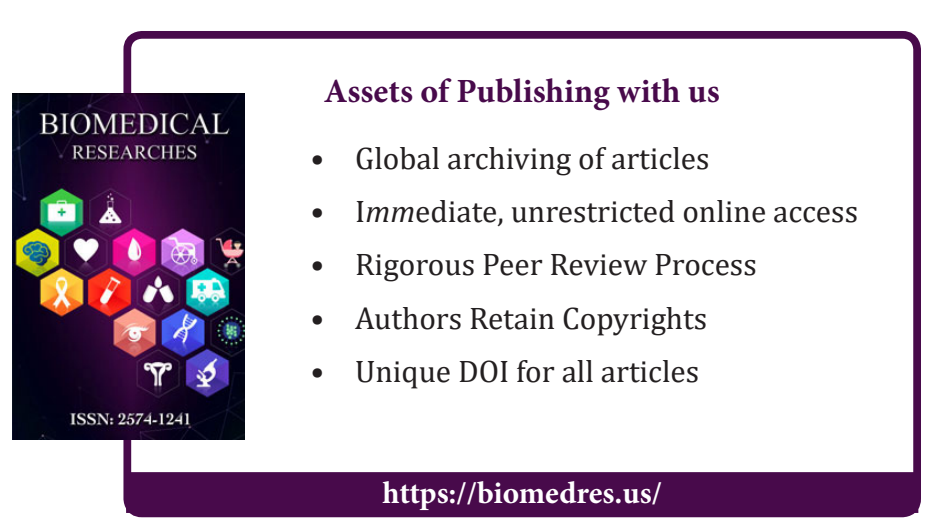

